\title{
PENGARUH LIQUIDITAS DAN SOLVABILITAS TERHADAP PROFITABILITAS PADA PT. SURYA TOTO INDONESIA, TBK PERIODE 2010-2019
}

\author{
${ }^{1 *}$ Hasanudin, ${ }^{2}$ Azhar Affandi \\ 1Universitas Pamulang, Tangerang Selatan, Banten, Indonesia \\ ${ }^{2}$ Universitas Pasundan, Bandung, Jawa Barat, Indonesia \\ *dosen02482@unpam.ac.id
}

\begin{abstract}
Abstrak
Penelitian ini bertujuan untuk mengetahui Pengaruh Liquiditas dan Solvabilitas Terhadap Profitabilitas Pada PT. Surya Toto Indonesia, Tbk. Metode yang digunakan adalah explanatory research. Teknik analisis menggunakan analisis statistik dengan pengujian regresi, korelasi, determinasi dan uji hipotesis. Hasil penelitian ini Current Ratio berpengaruh signifikan terhadap Return on Asset sebesar $42,7 \%$, uji hipotesis diperoleh $t$ hitung $>t$ tabel atau $(7,809>2,306)$. Debt to Asset Ratio berpengaruh signifikan terhadap Return on Asset sebesar 60,5\%, uji hipotesis diperoleh $t$ hitung $>t$ tabel atau $(8,595>2,306)$. Current Ratio dan Debt to Asset Ratio secara simultan berpengaruh signifikan terhadap Return on Asset diperoleh persamaan regresi $Y=2,162+-0,012+-0,195 X 2$ dan nilai determinasi sebesar 60,5\%, uji hipotesis diperoleh nilai F hitung > F tabel atau $(5,369>4,350)$.

Kata Kunci: Current Ratio, Debt to Asset Ratio, Return on Asset.

\section{Abstract}

This study aims to determine the effect of liquidity and solvency on profitability at PT. Surya Toto Indonesia, Tbk. The method used is explanatory research. The analysis technique uses statistical analysis with regression, correlation, determination and hypothesis testing. The results of this study that Current Ratio has a significant effect on Return on Assets of $42.7 \%$, hypothesis testing is obtained $t$ count $>t$ table or $(7.809>2,306)$. Debt to Asset Ratio has a significant effect on Return on Assets of 60.5\%, hypothesis testing is obtained $t$ count $>t$ table or $(8,595>2,306)$. Current Ratio and Debt to Asset Ratio simultaneously have a significant effect on Return on Assets obtained by the regression equation $Y=2.162+-0.012+-0.195 X 2$ and a determination value of $60.5 \% .4,350)$.
\end{abstract}

Keywords: Current Ratio, Debt to Asset Ratio, Return on Assets.

\section{PENDAHULUAN}

Setiap perusahaan akan melakukan berbagai aktivitas untuk mencapai tujuan yang telah ditetapkan. Tujuan akhir yang ingin dicapai suatu perusahaan yang terpenting adalah memperoleh laba atau keuntungan yang maksimal, disamping hal-hal lainnya. Dengan memperoleh laba yang maksimal seperti yang telah ditargetkan, perusahaan dapat berbuat banyak bagi kesejahteraan pemilik, karyawan, serta meningkatkan mutu produk dan melakukan investasi baru. Oleh karena itu, manajemen perusahaan dalam praktiknya dituntut harus mampu untuk memenuhi target yang telah ditetapkan.
Untuk mengukur tingkat keuntungan suatu perusahaan, digunakan rasio keuntungan atau rasio profitabilitas.

Bagi suatu perusahaan untuk memperoleh laba yang semaksimal mungkin, dapat dilakukan dengan memperbesar jumlah produksi yang dapat dijual. Salah satu faktor produksi terpenting ialah modal kerja yang digunakan perusahaan untuk membiayai operasi perusahaan demi menjamin kelangsungan hidup perusahaan. Maka dari itu, manajer keuangan harus mampu merencanakan dengan baik besarnya jumlah modal kerja yang efektif dan efisien di masa mendatang. 
Analisis keuangan yang mencakup rasio keuangan, analisis kelemahan dan kekuatan dibidang finansial akan sangat membantu dalam menilai prestasi manajemen masa lalu dan prospeknya dimasa datang. Dengan menganalisis prestasi keuangan, seorang analisis keuangan akan dapat menilai apakah manajer keuangan dapat merencanakan dan mengimplementasikan kedalam setiap tindakan secara konsisten dengan tujuan memaksimumkan kemakmuran pemegang saham. Penggunaan analisis rasio keuangan ini sangat bervariasi dan tergantung oleh pihak yang memerlukan. Disamping itu juga perlu disadari bahwa analisa rasio keuangan hanya memberikan gambaran satu sisi saja, oleh sebab itu masih diperlukan lagi tambahan data agar dapat lebih baik. Akhirnya analisis rasio keuangan hanya bermanfaat apabila dibandingkan standar yang jelas, seperti standar industri, kecenderungan atau standar tertentu sebagai tujuan manajemen. Selain itu perlu diperhatikan apabila membandingkan rasio satu perusahaan dengan perusahaan lain adalah menyangkut sistem akuntansi yang digunakan, kemampuan perusahaan memperoleh laba dalam hubungannya dengan penjualan, total aktiva maupun modal sendiri. Dengan demikian bagi investor jangka panjang akan sangat berkepentingan dengan analisis profitabilitas ini misalnya bagi pemegang saham akan melihat keuntungan yang benar-benar akan diterima dalam bentuk dividen (Agus Sartono, 2008).

Dalam memaksimumkan keuntungan selalu ada pertukaran dengan risiko. Semakin besar risiko yang dihadapi akan semakin besar pula keuntungan yang diharapkan. Seumpama kita diminta memilih antara dua proyek yang mempunyai risiko yang sama, kita akan memilih proyek yang akan memberikan imbalan atau perolehan yang lebih besar. Namun situasi yang sering dihadapi adalah apakah perolehan yang akan diterima cukup memadai untuk menutup risiko yang dihadapi. Pola yang dikembangkan untuk mengatasi masalah keuntungan dan risiko adalah memaksimumkan laba (maximize profit) disamping meminimumkan risiko (minimizing risk) (Budi Raharjo, 2007).

Profitabilitas menggambarkan kemampuan perusahaan untuk mendapatkan laba melalui semua kemampuan dan sumber yang ada seperti kegiatan penjualan, kas, modal, jumlah karyawan, jumlah cabang dan sebagainya. Rasio profitabilitas mengukur efektivitas manajemen secara keseluruhan yang ditunjukkan dengan besar kecilnya tingkat keuntungan yang diperoleh dalam hubungannya dengan penjualan maupun investasi (Sofyan Syafri Harahap, 2002).

Likuiditas merupakan suatu kondisi dari suatu perusahaan yang menunjukan kemampuan perusahaan untuk memenuhi kewajiban dalam jangka pendek dan dalam waktu yang tidak terlalu lama atau selalu siap jika suatu saat ditagih. Apabila perusahaan memiliki aktiva lancar lebih besar dari pada hutang lancar maka seharusnya perusahaan harus dapat memenuhi kewajiban keuangan tepat pada waktunya. Dengan kata lain, likuiditasnya bagus, namun sebaliknya jika perusahaan tidak mampu melaksanakan kewajiban pada saat ditagih, berarti hutang lancarnya lebih besar dari pada aktiva lancarnya, berarti dapat pula ditafsirkan dalam kondisi likuid (Abdulah Amrin, 2009).

Likuiditas mengacu pada kemampuan perusahaan untuk membayar untuk membayar beban-beban lancar dari operasinya (biasanya satu tahun atau kurang) dan hutang yang jatuh tempo. Enam ukuran likuiditas yang penting adalah perputaran piutang usaha, perputaran persediaan, rasio lancar, rasio cepat, dan rasio arus kas. Semakin tinggi rasio ini, semakin baik dan tinggi evaluasi terhadap profitabilitas perusahaan (Edward, Kung $\mathrm{H}$ Chen, Gery dan Thomas,2007).

Likuiditas mengukur kemampuan perusahaan untuk melunasi kewajiban utang jangka pendek tepat pada waktunya, termasuk melunasi bagian hutang jangka 
panjang yang jatuh tempo pada tahun bersangkutan. Likuiditas yang tinggi merupakan indikator bahwa risiko perusahaan rendah. Artinya perusahaan aman dari kemungkinan kegagalan membayar berbagai kewajiban lancar (Handono Mardiyanto, 2009).

Perusahaan semakin tinggi rasio lancar, seharusnya semakin besar kemampuan untuk membayar tagihannya. Rasio ini harus dianggap sebagai ukuran besar karena tidak mempertimbangkan likuiditas komponen individual aktiva lancar.

Perusahaan dengan aktiva lancar terdiri dari kas dan piutang tanpa jatuh tempo biasanya dianggap lebih likuid daripada perusahaan yang aktiva lancarnya terdiri dari persediaan (Van Horn, James C dan John M Wachowiez, 2000).

Perusahaan dengan kewajiban yang terlampau banyak akan mengalami kesulitan untuk mendapatkan tambahan dana dari luar. Kewajiban bukan sesuatu yang jelek jika dapat memberikan keuntungan kepada pemiliknya. Jika kewajiban dimanfaatkan dengan efektif dan laba yang didapat cukup untuk membayar biaya bunga secara periodik, laba yang diberikan kepada para pemegang saham ini disebut Solvabilitas. Secara Bahasa Solvabilitas berarti pengungkit (alat ungkit). Jadi, jika diterapkan dalam istilah keuangan, dapat dikatakan bahwa dengan usaha sedikit akat diperoleh hasil yang besar. Solvabilitas tercipta pada waktu laba perusahaan lebih besar dari pada bunga pinjaman yang harus dibayarnya (Kuswadi, 2005).

Menurut Kasmir (2008) Ratio Solvabilitas adalah ratio yang digunakan untuk mengukur sejauh mana aktiva perusahaan dibiaya dengan hutang. Artinya berapa besar beban hutang yang ditanggung perusahaan dibandingkan dengan aktivanya.

Pembiayaan dengan utang atau Solvabilitas memiliki tiga implikasi penting, yaitu: Pertama, memperoleh dana melalui utang membuat pemegang saham dapat mempertahankan pengendalian atas perusahaan dengan investasi yang terbatas. Kedua, kreditur melihat ekuitas atau dana yang disetor pemilik untuk memberikan marjin pengaman, sehingga jika pemegang saham hanya memberikan sebagian kecil dari total pembiayaan, maka risiko perusahaan sebagian besar ada pada kreditur. Ketiga, Jika perusahaan memperoleh pengembalian yang lebih besar atas investasi yang dibiayai dengan dana pinjaman dibanding pembayaran bunga, maka pengembalian atas modal pemilik akan lebih besar (Brigham dan Houston, 2001).

Tabel 1. Data Liquiditas, Solvabilitas dan

Profitabilitas PT. Surya Toto Indonesia, Tbk, Periode Tahun 2010-2019

\begin{tabular}{|c|c|c|c|}
\hline Tahun & $\begin{array}{c}\text { Liquiditas } \\
\text { CR }(\%)\end{array}$ & $\begin{array}{c}\text { Solvabilitas } \\
\text { DER }(\%)\end{array}$ & $\begin{array}{c}\text { Profitabilitas } \\
\text { ROA }(\%)\end{array}$ \\
\hline 2010 & 1.43 & 9.81 & 0.16 \\
\hline 2011 & 1.48 & 9.96 & 0.22 \\
\hline 2012 & 2.15 & 7.33 & 0.28 \\
\hline 2013 & 2.54 & 7.78 & 0.47 \\
\hline 2014 & 1.92 & 7.95 & 0.75 \\
\hline 2015 & 2.22 & 7.88 & 0.89 \\
\hline 2016 & 2.65 & 6.76 & 0.77 \\
\hline 2017 & 2.18 & 6.65 & 0.84 \\
\hline 2018 & 2.48 & 6.76 & 0.98 \\
\hline 2019 & 2.26 & 6.34 & 0.91 \\
\hline Rata- & & & 0.63 \\
rata & 2.13 & 7.72 & \\
\hline Sum & & & \\
\hline
\end{tabular}

Sumber: http://www.idx.co.id diolah

Dari data diatas dapat terlihat bahwa likuiditas pada tahun 2010 sampai dengan 2019 mengalami perkembangan yang fluktuasinamun berbanding terbalik dengan hasil profitabilitas keenam emiten ini yang justru mengalami penaikan hal ini di indikasikan karena kenaikan biaya produksi. Hal ini bertentangan dengan teori yang dinyatakan Handono Mardiyanto (2009:100) mengungkapkan bahwa peningkatan likuiditas justru akan menurunkan tingkat profitabilitas. Demikian juga sebaliknya. Likuiditas yang tinggi merupakan indikator bahwa resiko perusahaan rendah. Artinya, perusahaan aman dari kemungkinan kegagalan membayar berbagai kewajiban lancar. Namun hal itu harus merelakan rendahnya tingkat profitabilitas, yang akan berdampak terhadap rendahnya pertumbuhan perusahaan. Sebaliknya, 
jika perusahaan menginginkan profitabilitas yang tinggi, perusahaan harus bersedia menghadapi rendahnya likuiditas atau risiko yang kian meningkat atas kegagalan membayar atas kegagalan membayar kewajiban jangka pendek (yang bisa menyebabkan kebangkrutan usaha). Ketika profitabilitas perusahaan turun menandakan bahwa kinerja yang kurang baik dalam pencapaian laba perusahaan. Tetapi perusahaan masih dapat meningkatkan profitabilitas dengan cara memaksimal penggunaan hutang dalam menunjang yang terlihat dari solvabilitas sehingga dimana profitabilitas perusahaan akan meningkat seiring dengan peningkatan solvabilitas sebagaimana yang dinyatakan oleh I Made Sudana (2011:158) yang mengungkapkan bahwa Pengaruh hutang dalam pembelanjaan investasi perusahaan dapat mempengaruhi kemampuan perusahaan untuk menghasilkan laba atas modal yang digunakan (ROA).

Berdasarkan gambaran tersebut peneliti tertarik untuk meneliti mengenai "Pengaruh Liquiditas dan Solvabilitas Terhadap Profitabilitas Pada PT. Suryo Toto Indonesia Tbk".

\section{TINJAUAN PUSTAKA}

\section{Liquiditas}

Likuiditas adalah suatu kondisi dari suatu perusahaan yang menunjukan kemampuan perusahaan untuk memenuhi kewajiban dalam jangka pendek dan dalam waktu yang tidak terlalu lama atau selalu siap jika suatu saat ditagih (Abdullah Amrin,2009). Dalam penelitian ini menggunakan alat ukur Current Ratio

\section{Solvabilitas}

Solvabilitas merupakan ratio yang digunakan untuk mengukur sejauh mana aktiva perusahaan dibiayai dengan hutang. Artinya berapa besar beban hutang yang ditanggung perusahaan dibandingkan dengan aktivanya (Kasmir,2008). Dalam penelitian ini menggunakan alat uku Debt to Asset Ratio

\section{Profitabilitas}

Profitabilitas adalah hasil bersih dari sejumlah kebijakan dan keputusan yang dipilih oleh manajemen suatu organisasi (John A Pearce dan Richard B Robinson 2008:241). Dalam penelitian nii menggunakan alat ukur Return on Asset.

\section{METODE PENELITIAN}

\section{Populasi}

Populasi dalam penelitian ini berdasar laporan keuangan selama 10 tahun PT. Surya Toto Indonesia, Tbk

2. Sampel

Teknik pengambilan sampling dalam penelitian ini adalah samplel jenuh, dimana semua anggota populasi dijadikan sebagai sampel. Dengan demikian sampel dalam penelitian ini laporan keuangan selama 10 tahun.

3. Jenis Penelitian

Jenis penelitian yang dipakai adalah asosiatif, dimana tujuannya adalah untuk mengetahui mencari keterhubungan antar variabel independen terhadap variabel dependen

\section{Metode Analisis Data}

Dalam menganalisis data digunakan uji asumsi klasik, regresi, koefisien korelasi, koefisien determinasi dan uji hipotesis baik parsial maupun simultan.

\section{HASIL PENELITIAN}

\section{Analisis Deskriptif}

Pada pengujian ini digunakan untuk mengetahui besarnya persentase minimum dan maksimum, persentase rata-rata dan standar deviasi dari masing-masing variabel. Adapun hasilnya sebagai berikut:

Tabel 2. Hasil Analisis Descriptive Statistics Descriptive Statistics

\begin{tabular}{|c|c|c|c|c|c|}
\hline & \multicolumn{4}{|c|}{$x_{1}$} & \multirow[b]{2}{*}{$\begin{array}{c}\text { Std. } \\
\text { Deviatio } \\
\mathrm{n}\end{array}$} \\
\hline \multicolumn{2}{|r|}{$\mathrm{N}$} & $\begin{array}{c}\text { Minimu } \\
\mathrm{m}\end{array}$ & $\begin{array}{c}\text { Maximu } \\
\mathrm{m}\end{array}$ & $\begin{array}{c}\text { Mea } \\
\mathrm{n}\end{array}$ & \\
\hline CR (X1) & $\begin{array}{l}1 \\
0\end{array}$ & 1.43 & 2.65 & $\begin{array}{r}2.131 \\
0\end{array}$ & .41439 \\
\hline DER & 1 & \multirow[t]{2}{*}{6.34} & \multirow[t]{2}{*}{9.96} & 7.722 & \multirow[t]{2}{*}{1.26984} \\
\hline$(X 2)$ & 0 & & & 0 & \\
\hline ROA & 1 & \multirow[t]{2}{*}{.16} & \multirow[t]{2}{*}{.98} & .6270 & \multirow[t]{2}{*}{.31334} \\
\hline$(\mathrm{Y})$ & 0 & & & & \\
\hline
\end{tabular}




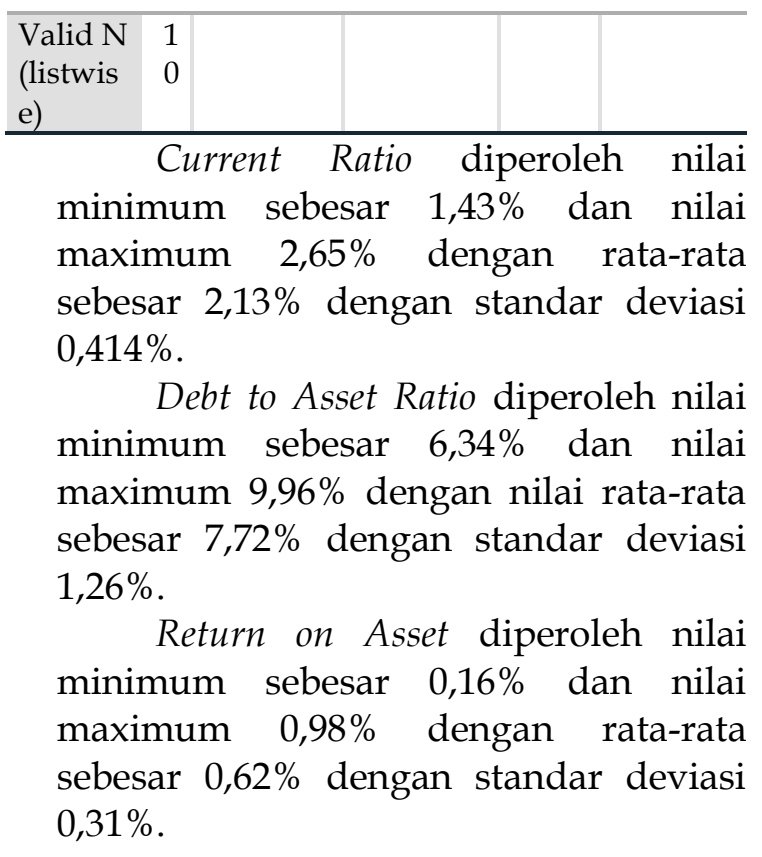

\section{Analisis Verifikatif.}

Pada analisis ini dimaksudkan untuk mengetahui pengaruh variabel independen terhadap variabel dependen. Adapun hasil pengujian sebagai berikut:

\section{a. Analisis Regresi Linier Berganda}

Uji regresi ini dimaksudkan untuk mengetahui perubahan variabel dependen jika variabel independen mengalami perubahan. Adapun hasil pengujiannya sebagai berikut:

Tabel 3. Hasil Pengujian Regresi Liner

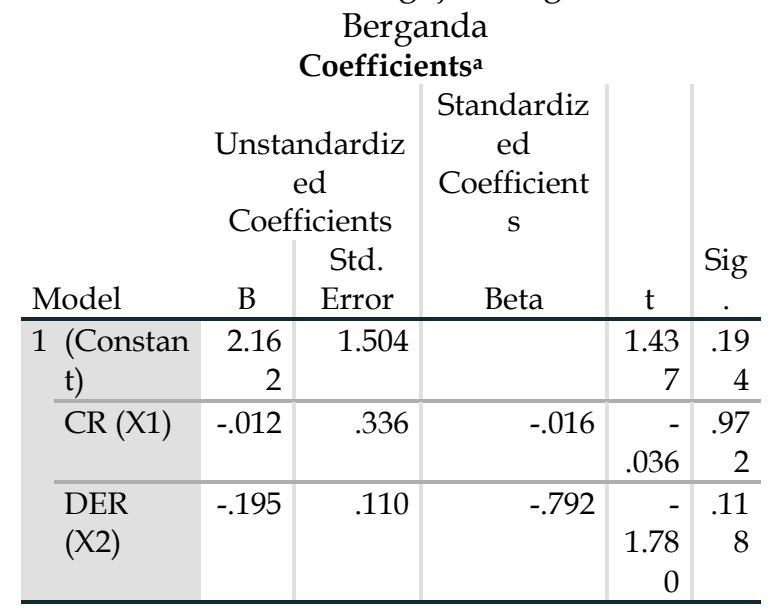

a. Dependent Variable: ROA (Y)

Berdasarkan hasil pengujian pada tabel di atas, diperoleh persamaan regresi $Y=2,162-0,012$ 0,195X2. Dari persamaan tersebut dijelaskan sebagai berikut:
1) Konstanta sebesar 2,162 diartikan jika Current Ratio dan Debt to Asset Ratio tidak ada, maka telah terdapat nilai Return on Asset sebesar 2,162 point.

2) Koefisien regresi Current Ratio sebesar -0,012, angka ini negatif artinya setiap ada penurunan Current Ratio sebesar -0,012 maka Return on Asset juga akan mengalami penurunan sebesar 0,012 point.

3) Koefisien regresi Debt to Asset Ratio sebesar -0,195, angka ini negatif artinya setiap ada penurunan Debt to Asset Ratio sebesar -0,195 maka Return on Asset juga akan mengalami penurunan sebesar -0,195 point.

\section{b. Analisis Koefisien Korelasi}

Analisis koefisien korelasi dimaksudkan untuk mengetahui tingkt kekuatan hubungan dari variabel independen terhadap variabel dependen baik secara parsial maupun simultan. Adapun hasil pengujian sebagai berikut:

Tabel 4. Hasil Pengujian Koefisien Korelasi Current Ratio Terhadap Return on Asset. Correlations $^{b}$

\begin{tabular}{llr|r} 
& & \multicolumn{2}{c}{ CR } \\
& & $(\mathrm{X} 1)$ & \multicolumn{1}{c}{ ROA (Y) } \\
\hline CR (X1) & $\begin{array}{l}\text { Pearson } \\
\text { Correlation }\end{array}$ & 1 & $.653^{*}$ \\
\cline { 2 - 3 } & Sig. (2-tailed) & & .041 \\
\hline ROA (Y) & $\begin{array}{l}\text { Pearson } \\
\text { Correlation }\end{array}$ & $.653^{*}$ & 1 \\
\cline { 2 - 4 } & Sig. (2-tailed) & .041 & \\
\hline
\end{tabular}

*. Correlation is significant at the 0.05 level (2tailed).

b. Listwise $\mathrm{N}=10$

Berdasarkan hasil pengujian diperoleh nilai korelasi sebesar 0,653 artinya Current Ratio memiliki hubungan yang kuat terhadap Return on Asset.

Tabel 5. Hasil Pengujian Koefisien Korelasi Debt to Asset Ratio Terhadap Return on Asset. Correlations $^{\mathrm{b}}$

\begin{tabular}{llr|r} 
& & DER (X2) & ROA (Y) \\
\hline DER (X2) & $\begin{array}{l}\text { Pearson } \\
\text { Correlation }\end{array}$ & 1 & $-.778^{* *}$ \\
\cline { 2 - 3 } & Sig. (2-tailed) & & .008
\end{tabular}




\begin{tabular}{llr|r}
\hline ROA (Y) & $\begin{array}{l}\text { Pearson } \\
\text { Correlation }\end{array}$ & $-.778^{* *}$ & 1 \\
\cline { 2 - 4 } & Sig. (2-tailed) & .008 & \\
\hline
\end{tabular}

**. Correlation is significant at the 0.01 level (2tailed).

b. Listwise $\mathrm{N}=10$

Berdasarkan hasil pengujian diperoleh nilai korelasi sebesar -0,778 artinya Debt to Asset Ratio memiliki hubungan yang negatif kuat terhadap Return on Asset.

Tabel 6. Hasil Pengujian Koefisien Korelasi Current Ratio dan Debt to Asset Ratio secara simultan Terhadap Return on Asset. Model Summary

\begin{tabular}{l|l|l} 
R & Adjusted Std. Error of the
\end{tabular}

\begin{tabular}{lr|r|rr} 
Model & $R$ & Square & R Square & \multicolumn{2}{c}{ Estimate } \\
\hline 1 & $.778^{\mathrm{a}}$ & .605 & .493 & .22319 \\
\hline \multicolumn{2}{l}{ a. Predictors: (Constant), DER (X2), CR (X1) }
\end{tabular}

a. Predictors: (Constant), DER (X2), CR (X1)

Berdasarkan hasil pengujian diperoleh nilai korelasi sebesar 0,778 artinya Current Ratio dan Debt to Asset Ratio secara simultan memiliki hubungan yang kuat terhadap Return on Asset.

\section{c. Analisis Koefisien Determinasi}

Analisis koefisien determinasi dimaksudkan untuk mengetahui besarnya persentase pengaruh dari variabel independen terhadap variabel dependen baik secara parsial maupun simultan. Adapun hasil pengujian sebagai berikut:

Tabel 7. Hasil Pengujian Koefisien

Determinasi Current Ratio Terhadap Return on Asset.

\begin{tabular}{|c|c|c|c|c|}
\hline \multicolumn{5}{|c|}{ Model Summary } \\
\hline Model & $\mathrm{R}$ & $\begin{array}{c}\mathrm{R} \\
\text { Square }\end{array}$ & $\begin{array}{l}\text { Adjusted } \\
\text { R Square }\end{array}$ & $\begin{array}{l}\text { Std. Error of the } \\
\text { Estimate }\end{array}$ \\
\hline 1 & $.653^{\mathrm{a}}$ & .427 & .355 & .25164 \\
\hline
\end{tabular}

Berdasarkan hasil pengujian diperoleh nilai determinasi sebesar 0,427 artinya Current Ratio memiliki kontribusi pengaruh sebesar $42,7 \%$ terhadap Return on Asset.

Tabel 8. Hasil Pengujian Koefisien Determinasi Debt to Asset Ratio Terhadap Return on Asset.

Model Summary

\begin{tabular}{c|c|c}
$\mathrm{R}$ & Adjusted & Std. Error of the
\end{tabular}

\begin{tabular}{|c|c|c|c|c|}
\hline Model & $\mathrm{R}$ & Square & R Square & Estimate \\
\hline 1 & $.778^{a}$ & .605 & .556 & .20879 \\
\hline
\end{tabular}

a. Predictors: (Constant), DER (X2)
Berdasarkan hasil pengujian diperoleh nilai determinasi sebesar 0,605 artinya Debt to Asset Ratio memiliki kontribusi pengaruh sebesar 60,5\% terhadap Return on Asset.

Tabel 9. Hasil Pengujian Koefisien Determinasi Current Ratio dan Debt to Asset Ratio Terhadap Return on Asset. Model Summary

\begin{tabular}{l|l|l}
$\mathrm{R}$ & Adjusted & Std. Error of the
\end{tabular} \begin{tabular}{ll|l|l} 
Model $\mathrm{R}$ & Square & $\mathrm{R}$ Square & Estimate
\end{tabular}

\begin{tabular}{ccccc}
\hline 1 & $.778^{\mathrm{a}}$ & .605 & .493 & .22319 \\
\hline
\end{tabular}
a. Predictors: (Constant), DER (X2), CR (X1)

Berdasarkan hasil pengujian diperoleh nilai determinasi sebesar 0,605 artinya Current Ratio dan Debt to Asset Ratio secara simultan memiliki kontribusi pengaruh sebesar 60,5\% terhadap Return on Asset, sedangkan sisanya sebesar 39,5\% dipengaruhi faktor lain.

\section{d. Uji Hipotesis}

\section{Uji hipotesis Parsial (Uji t)}

Pengujian hipotesis dengan uji $t$ digunakan untuk mengetahui hipotesis parsial mana yang diterima. Tabel 10. Hasil Uji Hipotesis Current Ratio Terhadap Return on Asset. Coefficients ${ }^{a}$

\begin{tabular}{|c|c|c|c|c|c|}
\hline \multirow[b]{3}{*}{ Model } & \multicolumn{3}{|c|}{ Coefficients $^{a}$} & \multirow[b]{3}{*}{$\mathrm{t}$} & \multirow[b]{3}{*}{ Sig } \\
\hline & \multicolumn{2}{|c|}{$\begin{array}{c}\text { Unstandardiz } \\
\text { ed } \\
\text { Coefficients }\end{array}$} & $\begin{array}{l}\text { Standardiz } \\
\text { ed } \\
\text { Coefficient } \\
\text { s }\end{array}$ & & \\
\hline & B & $\begin{array}{l}\text { Std. } \\
\text { Error }\end{array}$ & Beta & & \\
\hline 1 (Constan & - & .439 & & - & .36 \\
\hline t) & .426 & & & .970 & 0 \\
\hline CR (X1) & .494 & .202 & .653 & 2.44 & .04 \\
\hline
\end{tabular}

a. Dependent Variable: ROA (Y)

Berdasarkan hasil pengujian pada tabel di atas, diperoleh nilai $\mathrm{t}$ hitung $>\mathrm{t}$ tabel atau $(7,809>2,306)$, dengan demikian terdapat pengaruh yang signifikan atara Current Ratio terhadap Return on Asset. 
Tabel 11. Hasil Uji Hipotesis Debt to Asset Ratio Terhadap Return on Asset. Coefficients ${ }^{a}$

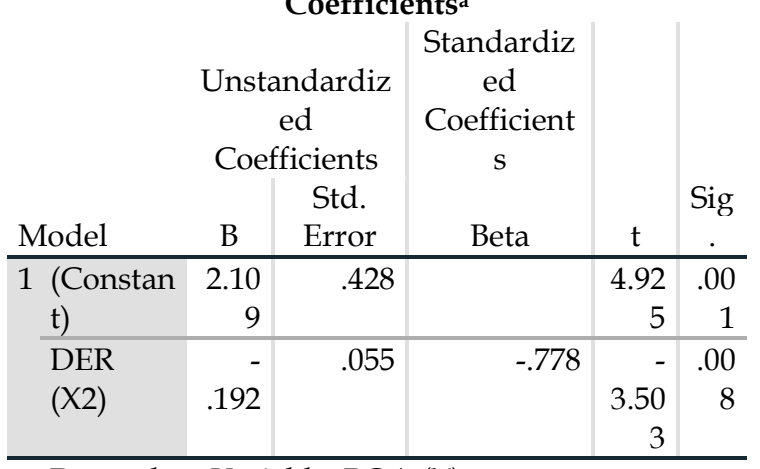

a. Dependent Variable: ROA (Y)

Berdasarkan hasil pengujian pada tabel di atas, diperoleh nilai $\mathrm{t}$ hitung $>\mathrm{t}$ tabel atau $(8,595>2,306)$, dengan demikian terdapat pengaruh yang signifikan atara Debt to Asset Ratio terhadap Return on Asset.

\section{Uji Hipotesis Simultan (Uji F)}

Pengujian hipotesis dengan uji $\mathrm{F}$ digunakan untuk mengetahui hipotesis simultan yang mana yang diterima.

Tabel 12. Hasil Uji Hipotesis Current Ratio dan Debt to Asset Ratio Terhadap Return on Asset. ANOVA $^{a}$

\begin{tabular}{|c|c|c|c|c|c|c|}
\hline \multirow{2}{*}{\multicolumn{2}{|c|}{ Model }} & \multicolumn{3}{|c|}{ ANUVA $A^{a}$} & \multirow[b]{2}{*}{ F } & \multirow[b]{2}{*}{ Sig. } \\
\hline & & $\begin{array}{l}\text { Sum of } \\
\text { Squares }\end{array}$ & $\mathrm{df}$ & $\begin{array}{l}\text { Mean } \\
\text { Square }\end{array}$ & & \\
\hline \multirow[t]{3}{*}{1} & Regression & .535 & 2 & .267 & 5.369 & $.039 \mathrm{~b}$ \\
\hline & Residual & .349 & 7 & .050 & & \\
\hline & Total & .884 & 9 & & & \\
\hline
\end{tabular}

a. Dependent Variable: ROA (Y)

b. Predictors: (Constant), DER (X2), CR (X1)

Berdasarkan hasil pengujian pada tabel di atas, diperoleh nilai $\mathrm{F}$ hitung $>$ F tabel atau $(5,369>4,350)$, dengan demikian terdapat pengaruh yang signifikan atara Current Ratio dan Debt to Asset Ratio terhadap Return on Asset.

\section{PEMBAHASAN HASIL PENELITIAN}

\section{Pengaruh Current Ratio Terhadap}

\section{Return on Asset}

Current Ratio berpengaruh signifikan terhadap Return on Asset dengan korelasi sebesar 0,653 atau memiliki hubungan yang kuat dengan kontribusi pengaruh sebesar 42,7\%. Pengujian hipotesis diperoleh nilai $t$ hitung $>\mathrm{t}$ tabel atau $(7,809>2,306)$. Dengan demikian terdapat pengaruh signifikan antara Current Ratio terhadap Return on Asset.

\section{Pengaruh Debt to Asset Ratio} Terhadap Return on Asset

Debt to Asset Ratio berpengaruh signifikan terhadap Return on Asset dengan korelasi sebesar $-0,778$ atau memiliki hubungan yang kuat dengan kontribusi pengaruh sebesar 60,5\%. Pengujian hipotesis diperoleh nilai $t$ hitung $>\mathrm{t}$ tabel atau $(8,595>2,306)$. Dengan demikian terdapat pengaruh signifikan antara Debt to Asset Ratio terhadap Return on Asset.

\section{Pengaruh Current Ratio dan Debt to} Asset Ratio Terhadap Return on Asset

Current Ratio dan Debt to Asset Ratio berpengaruh signifikan terhadap Return on Asset dengan diperoleh persamaan regresi $\mathrm{Y}=2,162-0,012-0,195 X 2$, nilai korelasi sebesar 0,778 atau memiliki hubungan yang kuat dengan kontribusi pengaruh sebesar 60,5\% sedangkan sisanya sebesar $39,5 \%$ dipengaruhi faktor lain. Pengujian hipotesis diperoleh nilai $\mathrm{F}$ hitung > F tabel atau $(5,369>4,350)$. Dengan demikian terdapat pengaruh signifikan antara Current Ratio dan Debt to Asset Ratio terhadap Return on Asset.

\section{KESIMPULAN DAN SARAN \\ Kesimpulan}

a. Current Ratio berpengaruh signifikan terhadap Return on Asset dengan kontribusi pengaruh sebesar $42,7 \%$. Uji hipotesis diperoleh nilai thitung $>\mathrm{t}$ tabel atau $(7,809>2,306)$.

b. Debt to Asset Ratio berpengaruh signifikan terhadap Return on Asset dengan kontribusi pengaruh sebesar $60,5 \%$. Uji hipotesis diperoleh nilai $t$ hitung $>\mathrm{t}$ tabel atau $(8,595>2,306)$.

c. Current Ratio dan Debt to Asset Ratio berpengaruh signifikan terhadap Return on Asset dengan kontribusi pengaruh sebesar $60,5 \%$ sedangkan sisanya sebesar $39,5 \%$ dipengaruhi faktor lain. Uji 
hipotesis diperoleh nilai $\mathrm{F}$ hitung $>\mathrm{F}$ tabel atau $(5,369>4,350)$.

\section{Saran}

a. Perusahaan harus memperhatikan tingkat likuiditasnya, dimana kemampuan perusahaan dalam memenuhi kewajiban-kewajiban masih belum optimal karena tingkat kemampuan perusahaan dibeberapa tahun penelitian banyak mengalami penurunan. Walaupun dalam membayarkan hutang perusahaan tetap dapat terkendali.

b. Perusahaan harus memperhatikan tingkat aktifitasnya, dimana kemampuan perusahaan untuk menciptakan penjualan dengan menggunakan seluruh aktiva yang dimilikinya.

c. Perusahaan harus memperhatikan tingkat profitabilitas, Hal ini masih dapat diperbaiki dengan mengupayakan keuntungan yang maksimal diantaranya mengupayakan tagihan atau piutang yang bermasalah atau semaksimalkan pengembalian secara tepat waktu yang selanjutnya akan menambah jumlah keuntungan.

\section{DAFTAR PUSTAKA}

Agus Harjito \& Martono, (2010) "Manajemen Keuangan" Yogyakarta: Penerbit Ekonisia.

Agus Sartono. (2010). "Manajemen Keuangan Toeri dan Aplikasi", Edisi keempat, Yogyakarta: Penerbit BPFE.

Algifari. (2015). “Analisis Regresi untuk Bisnis dan Ekonomi". Yogyakarta: BPFE.

Arikunto, Suharsimi (2014). "Prosedur Penelitian Suatu Pendekatan Praktek". Jakarta: Rineka Cipta.

Bambang Riyanto, (2011). "Dasar-dasar Pembelanjaan Perusahaan". Edisi ke empat, BPFE Yogyakarta.

Brigham, F. Eugene dan Joel, F. Houston. "Dasar-dasar Manajemen Keuangan".Edisi Kesepuluh, JilidI.
Salemba Empat. Jakarta : 2008

Fahmi, Irham (2012), "Pengantar Manajemen Keuangan" Cetakan pertama. Bandung: Penerbit Alfabeta. Haque, M. G., Nurjaya, N.,Affandi, A., Erlangga, H., \& Sunarsi, D. (2021). Micro Financial Sharia Non-bank Strategic Analysis: a Study at BMT Beringharjo, Yogyakarta. Budapest International Research and Critics Institute (BIRCI-Journal): Humanities and Social Sciences, 4(2), 1677-1686.

Harahap, Sofyan Safri. "Analisis Kritis Atas Laporan Keuangan". Raja Grafindo Persada. Jakarta : 2002

Hasibuan, Malayu S.P "Pengantar Manajemen". CV. Alfabeta. Bandung : 2012

Hushan, Suad dan Enny Pudjiastuti. "Dasardasar Manajemen Keuangan".Edisi Keenam. UPP STIM YKPN. Jogyakarta:2012

Imam Ghozali (2017). "Aplikasi Analisis Multivariate Dengan Program SPSS". Edisi Kelima. Semarang: Badan Penerbit Undip.

Istijanto (2014) "Riset Sumber Daya Manusia". Jakarta: PT. Gramedia Pustaka

Jasmani, J. (2019). The Effect of Liquidity and Working Capital Turnover on Profitability at PT. Sumber Cipta Multiniaga, South Jakarta. PINISI Discretion Review, 3(1), 29-38.

Kasmir (2010), “Analisis Laporan keuangan", penerbit raja grafindo persada, Jakarta

Kasmir. “Analisis Laporan Keuangan”. PT. Rajawali Persada Jakarta : 2014

Kasmir. "Analisis Laporan Keuangan". Raja Grafindo Persada Jakarta : 2012

Kharis, Ismu Fadli (2011). “Studi Mengenai Impulse Buying dalam Penjualan Online". Semarang : Skripsi Universitas Diponegoro

Lutfi, A. M., Erlangga, H., Nurjaya, N., Priadana, S., \& Dwiwarman, D. A. (2021). Pengaruh Capital Adequacy Ratio Dan Bopo Ratio Terhadap 
Return On Asset Pada Pt. Bank Muamalat Indonesia, Tbk Periode 2010-2019. Jurnal Ekonomi Efektif, 3(3).

Martono dan Agus Harjito, (2011). "Manajemen Keuangan", Jakarta: Penerbit Ekonisia..

Martono dan Agus Harjito."Manajemen Keuangan". Ekonosia.Yogyakarta : 2010

Munawir (2010), “Analisis Laporan Keuangan", Edisi Ke Empat, Penerbit Liberty, Yogyakarta.

Najibullah, et al. (2021). Pengaruh non Performing Financing dan Financing to Deposit Ratio terhadap Pembiayaan pada Bank DKI Syariah. Jurnal Neraca Peradaban. Volume 1. Issue1. Pages 48-5

Nurjaya, et al (2021). Pengaruh Liquiditas dan Profitabilitas terhadap Return Saham: Studi Empiris Pada Perusahaan Real Estate Dan Property Yang Terdaftar Di Bursa Efek Indonesia Tahun 2017-2019. Jurnal Tadbir Peradaban Volume 1. Issue.1. Pages 60-68.

Pujiati, H., Sunarsi, D., Affandi, A., \& Anggraeni, N. (2021). Effect of ISO 9001: 2015 Quality Management Implementation in Education on School Performance. Journal of Contemporary Issues in Business and Government, 27(1), 1848-1855.

Pujiati, H., Sunarsi, D., Affandi, A., \& Anggraeni, N. (2021). Effect of ISO 9001: 2015 Quality Management Implementation in Education on School Performance. Journal of Contemporary Issues in Business and Government, 27(1), 1848-1855.

Rodoni, A, Ali, H. "Manajemen Keuangan". Mitra Wacana Media. Jakarta : 2010
S.Munawir."Analisa Laporan Keuangan". Liberty. Jogyakarta:2013 (Edisi Keempat)

Salam, A., Hikmat, I., Haquei, F., \& Badariah, E. (2021). The Influence of Share Ownership, Funding Decisions, Csr and Financial Performance of Food Industry. Annals of the Romanian Society for Cell Biology, 12698-12710.

Santoso, Singgih (2015). "Menguasai Statistik Multivariat". Jakarta: PT Elex Media Komputindo.

Sartono, "Manajemen Keuangan Aplikasi Dan Teori", Edisi Keempat, BPFE, Yogyakarta, 2008.

Sawir, (2003). “Analisis Kinerja Keuangan dan Perencanaan Keuangan Perusahaan", Cetakan ketiga, Jakarta: Penerbit PT. Gramedia Pustaka Utama.

Siswanto, H, B. "Pengantar Manajemen". BumiAksara. Jakarta : 2011

Sugiyarso, G. dan F. Winarni, "Manajemen Keuangan (Pemahaman Laporan Keuangan, Pengelolaan Aktiva, Kewajiban dan Modal serta Pengukuran

Sugiyono (2017), “Metode Penelitian Administrasi : dilengkapi dengan Metode R \& D". Bandung: Alfabeta.

Sugiyono. "Metode Penelitian Kuantitatif, Kualitatif dan RED". Alfabeta.Bandung : 2009

Sutrisno."Manajemen Keuangan Teori, Konsep, dan Aplikasi". Ekonosia.Yogyakarta : 2005

Wijaya, Toni. "Cepat Menguasai SPSS 20" Cahaya Atma Pustaka. Yogyakarta:2012

Wiratna Sujarweni, V. "Metodologi Penelitian".Pustaka Baru Press.Yogyakarta : 2014. 